\title{
INVESTIGATION OF THE WEAR BEHAVIOUR OF AN AISI 1040 FORGED STEEL SHAFT WITH PLASMA-SPRAY CERAMIC-OXIDE COATINGS FOR SUGAR-CANE MILLS
}

\author{
RAZISKAVA OBRABE AISI 1040 KOVANE JEKLENE GREDI S \\ KERAMIČNIMI OKSIDNIMI PREVLEKAMI ZA MLINE ZA \\ MLETJE SLADKORNEGA TRSA
}

\author{
Duraisamy Revathi Ponnusamy Rajarathnam', Murugesan Jayaraman² \\ ${ }_{1}^{1}$ Paavai Engineering College, Department of Mechanical Engineering, Namakkal District, India \\ ${ }^{2}$ Velalar College of Engineering and Technology, Department of Mechanical Engineering, Erode District, India \\ drprajamalathi@yahoo.co.in \\ Prejem rokopisa - received: 2017-03-27; sprejem za objavo - accepted for publication: 2017-05-19
}

doi:10.17222/mit.2017.035

\begin{abstract}
In this investigation, ceramic oxide powders, alumina, titania, chromia, alumina-titania, alumina-chromia and titania-chromia, were coated for a thickness of $200 \mu \mathrm{m}$ on an AISI 1040 forged steel substrate by means of an atmospheric plasma spraying method. Ni-Cr was used as an intermediate bond coat of thickness $20 \mu \mathrm{m}$ over the substrate to improve the coating adhesion. Pin-on-disc apparatus was employed for a dry wear test as per the American Society for Testing and Materials G99 standards for a constant load of $10 \mathrm{~N}$, at different sliding distances of $1000 \mathrm{~m}, 2000 \mathrm{~m}$ and $3000 \mathrm{~m}$, respectively. The investigation shows that the microstructure, coating thickness, porosity, surface roughness and hardness influence the wear rate. Before and after the wear tests, surface roughness measurements were carried out by using a talysurf instrument on the specimens. It is shown that the highest value $(20.89 \mu \mathrm{m})$ was obtained for the coating of alumina-titania. The practical results show that the pure chromia coated specimen has a very good wear-resistance property compared to the ceramic oxides. This suggests that surface coating with pure chromia on the top mill roll shaft of sugar industries enhanced the wear resistance.

Keywords: alumina, titania, chromia, atmospheric plasma spray, pin-on-disc, wear, Talysurf profilometer

V raziskavi so bili oksidni praški: glinica, titan, krom, aluminijev oksid, aluminij-krom, prevlečeni z $200 \mu$ m na AISI 1040 podlago kovanega jekla $z$ metodo naprševanja s plazmo. Ni-Cr smo uporabili kot vmesni vezni premaz z debelino $20 \mu \mathrm{m}$ nad podlago za izboljšanje oprijemljivosti prevleke. Pin-on-disk aparat je bila uporabljen za preskus suhe obrabe, v skladu s standardi G99 Ameriškega združenja za testiranje in materiale, s konstantno obremenitvijo $10 \mathrm{~N}$, na različnih drsnih razdaljah $1000 \mathrm{~m}, 2000 \mathrm{~m}$ in $3000 \mathrm{~m}$. Preiskava je pokazala, da so mikrostruktura, debelina prevleke, poroznost, površinska hrapavost in trdota vplivali na stopnjo obrabe. Pred in po testih obrabe, so bile meritve vzorcev površinske hrapavosti izvedene z uporabo Talysurf instrumenta. Izkazalo se je, da je največja vrednost $(20,89 \mu \mathrm{m})$, pridobljena s prevleko iz aluminijevega oksida-titanovega dioksida. Praktični rezultati kažejo, da ima s čistim kromom prevlečen vzorec zelo dobro odpornost na obrabo kot tisti s keramičnimi oksidi. Kaže, da površinska prevleka s čistim kromom na zgornji gredi mlina v sladkorni industriji poveča odpornost proti obrabi.

Ključne besede: aluminij, titan, krom, atmoferski plazma sprej, spoj na disk, obraba, Talysurf profilometer
\end{abstract}

\section{INTRODUCTION}

In many sugar industries, the top mill roller shaft, used to crush sugarcane, is made up of AISI 1040 forged carbon steel as this medium carbon, tensile steel shows good strength, toughness and wear resistance. The roller shaft has to operate under critical working conditions such as heavy load, high speed, temperature and chemical environment, while it crushes the raw sugar cane to extract the sugar cane juice. Hence, surface hardening of the shaft is a must to improve the wear resistance as they suffer from various types of degradation. Generally, the shaft diameter will decrease due to continuous rotation with a speed of $4 \mathrm{~min}^{-1}$ and accumulation of various impurities such as bagasse, ferrous and non-ferrous metals and also due to improper lubrications in between the journal bearing and the shaft. Hence, the shaft surface at the pinion end should be coated with ceramic materials with a good wear-resistance property.

The coating layer is very important because it enhances the wear resistance of the metal substrate of AISI 1040 forged steel to increase its life and efficiency. Some of the most commonly used ceramic materials in industrial applications are alumina $\left(\mathrm{Al}_{2} \mathrm{O}_{3}\right)$, titania $\left(\mathrm{TiO}_{2}\right)$, Chromia $\left(\mathrm{Cr}_{2} \mathrm{O}_{3}\right)$. S.-H. Yao ${ }^{1}$ studied nanostructured $\mathrm{Al}_{2} \mathrm{O}_{3}$ with $13 \%$ of mass fractions of $\mathrm{TiO}_{2}$ coatings and found that they showed better performance in hardness and wear. Y. Sert et al. ${ }^{2}$ studied the wear resistance of the plasma sprayed alumina - titania, titania, chromia and chromia - titania and found the effect of $\mathrm{TiO}_{2}$ content on $\mathrm{Al}_{2} \mathrm{O}_{3}-\mathrm{TiO}_{2}$ and $\mathrm{Cr}_{2} \mathrm{O}_{3}-\mathrm{TiO}_{2}$ coatings on Al-based substrate, and concluded that hardness, coating density and wear resistance changed with the $\mathrm{TiO}_{2}$ content. 
B. A. Khan et al. ${ }^{3}$ studied the microstructural, surface roughness and tribological properties of a coated specimen with alumina, titania and alumina-titania coating materials and the results showed that pure alumina has better wear properties than other coating materials, and it was observed that the thermal barrier coating decreases the wear rate compared to the parent metal. M. H. Korkut et al. ${ }^{4}$ studied the wear behaviour of the ceramic surfaces over different test durations on AISI 1040 mild steel and found that the pure chromium III oxide $\left(\mathrm{Cr}_{2} \mathrm{O}_{3}\right)$ has a higher wear resistance than pure $\mathrm{Al}_{2} \mathrm{O}_{3}$ and its compositions with $\mathrm{TiO}_{2}$, they concluded that wear resistance decreased with an increase in the percentage of $\mathrm{TiO}_{2}$ powder in $\mathrm{Al}_{2} \mathrm{O}_{3}$ mixture.

$\mathrm{S}$. Islak et al. ${ }^{5}$ investigated the effect of $\mathrm{TiO}_{2}$ rate in an $\mathrm{Al}_{2} \mathrm{O}_{3}-\mathrm{TiO}_{2}$ composite coating on SAE 1040 steel and observed that the phase transformations take place from stable $\alpha-\mathrm{Al}_{2} \mathrm{O}_{3}$ and anatase $\mathrm{TiO}_{2}$ to metastable $\gamma-\mathrm{Al}_{2} \mathrm{O}_{3}$, rutile $\mathrm{TiO}_{2}$ and $\mathrm{Al}_{2} \mathrm{TiO}_{5}$ phase and as a result the microhardness value was found to be 3 to 4.5 times higher than that of SAE 1040 steel substrate materials due to a decrease in pore content when the $\mathrm{TiO}_{2}$ powder rate increased in the composition. S. Salman et al. ${ }^{6}$ investigated the thermal shock resistance of various ceramic oxides coated on a cast iron substrate and found that zirconia coated samples deformed at $1040{ }^{\circ} \mathrm{C}$ after $37 \mathrm{~s}$ when compared to $\mathrm{Cr}_{2} \mathrm{O}_{3}$ which deformed at $960{ }^{\circ} \mathrm{C}$ after $33 \mathrm{~s}$. It was concluded that the $\mathrm{Al}_{2} \mathrm{O}_{3}$ coated specimen has less thermal shock resistance since it deformed at $920{ }^{\circ} \mathrm{C}$ in $31 \mathrm{~s}$.

M. S. Kumar et al. ${ }^{7}$ analyzed the tribological properties of thermally sprayed WC $-12 \%$ of mass fractions of $\mathrm{Co}$ and $\mathrm{Al}_{2} \mathrm{O}_{3}-13 \%$ of mass fractions of $\mathrm{TiO}_{2}$ on AISI 1040 steel used in the automobiles and found that the wear failure mechanism gets influenced more at higher temperatures around $600{ }^{\circ} \mathrm{C}$. It was also observed that a carbide coating exhibited denser microstructured and higher hardness than ceramic oxide coatings. G. Bolleli et al. ${ }^{8}$ investigated the wear behaviour of plasma-sprayed ceramic coatings $\left(\mathrm{Al}_{2} \mathrm{O}_{3}, \mathrm{Al}_{2} \mathrm{O}_{3}-13 \%\right.$ of mass fractions of $\mathrm{TiO}_{2}$ and $\mathrm{Cr}_{2} \mathrm{O}_{3}$ ) and found that the $\mathrm{Cr}_{2} \mathrm{O}_{3}$ coating was the hardest and most anisotropic among the other plasma-sprayed ceramics due to the low interlamellar cohesion, whereas the $\mathrm{Al}_{2} \mathrm{O}_{3}-13 \%$ of mass fractions of $\mathrm{TiO}_{2}$ was less hard and tough due to the formation of a glassy phase and turns out to be quite brittle.

A. Prasad et al. ${ }^{9}$ investigated the hardness of a $\mathrm{Ni} / \mathrm{La}_{2} \mathrm{O}_{3}$ composite powder that was cladded over AISI 1040 steel through microwave irradiation to improve the wear resistance and observed the averaged Vickers microhardness was about $319 \mathrm{HV}$. It was further stated that the hardness value depends upon the particle size, microwave power and microwave exposure time. M. S. Gök ${ }^{10}$ studied the microstructure and abrasive wear performance of an AISI 1040 steel surface coated with different ceramic materials and observed that a higher rate of $\mathrm{Cr}_{2} \mathrm{O}_{3}$ in the composition produced a better and higher microhardness value than other ceramic coating materials. They also showed that increasing the proportion of $\mathrm{TiO}_{2}$ in the composition affects the microhardness value of the specimen.

P. Gadhari et al. ${ }^{11}$ studied the wear behaviour of a N-P- $\mathrm{Al}_{2} \mathrm{O}_{3}$ composite coating on AISI 1040 steel and showed that a change in the parameters like higher annealing temperature $500{ }^{\circ} \mathrm{C}$ and reducing agent concentration $(25 \mathrm{~g} / \mathrm{L})$ improved the wear resistance of the coating. The amount of alumina content affects the wear resistance property of the composite coating. M. Yunus et al. ${ }^{12}$ investigated the wear behaviour of ceramic coatings on a mild-steel substrate which has vast applications in aerospace, gas turbine engines and power generators. The result showed that the partially stabilized zirconia (PSZ) has more thermal barrier and thermal cycling resistance than alumina-titania and alumina. The coating temperature $\left(1000{ }^{\circ} \mathrm{C}\right)$, types of coating and thickness of coating affect or influence the thermal barrier against the ceramic coating materials.

\section{EXPERIMENTAL PART}

\subsection{Substrate preparation}

AISI 1040 forged steel was used as a substrate material provided by M/s.Coimbatore Metal Mart. The substrate AISI 1040 forged steel was made into circular pins of $8 \mathrm{~mm}$ diameter and $30 \mathrm{~mm}$ length by performing turning and facing operations in the lathe machine from its original dimension of $30 \mathrm{~mm}$ diameter and $40 \mathrm{~mm}$ length. Three types of coating materials were used: ceramic oxide powders (99\% of mass fractions) $\mathrm{Al}_{2} \mathrm{O}_{3}$ as fused, primarily $\alpha$-phase with particle -325 mesh size, (99\% of mass fractions) $\mathrm{TiO}_{2}$ traces metal basis with particle -325 mesh size, (98\% of mass fractions) $\mathrm{Cr}_{2} \mathrm{O}_{3}$ with particle size $5 \mu \mathrm{m}$ provided by Sigma Aldrich Chemicals Pvt Ltd, Bangalore, India. The mixtures formed with six different compositions are shown in Table $\mathbf{1 .}$

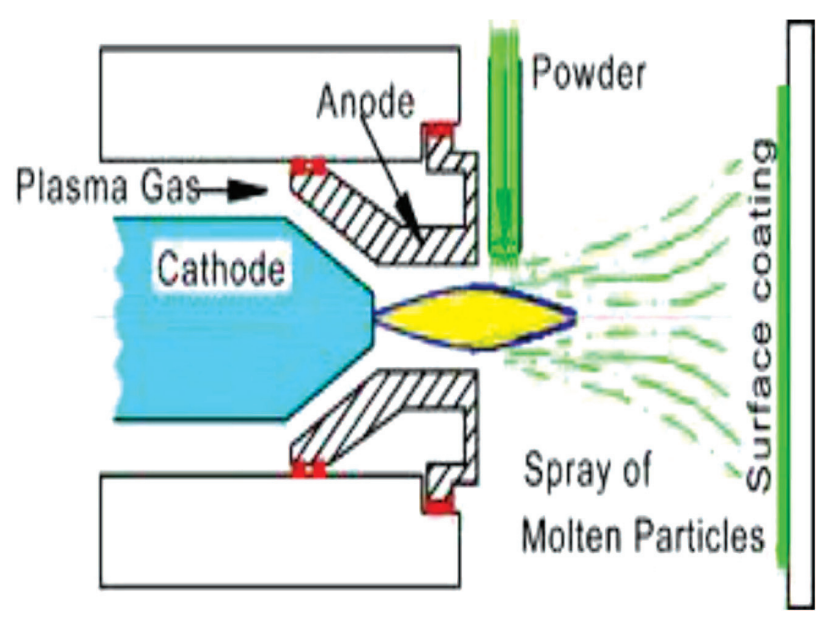

Figure 1: Schematic picture of plasma spray coating 


\section{MATERIALI IN TEHNOLOGIJE/MATERIALS AND TECHNOLOGY (1967-2017) - 50 LET/50 YEARS}

D. R. PONNUSAMY RAJARATHNAM, M. JAYARAMAN: INVESTIGATION OF THE WEAR BEHAVIOUR OF AN AISI 1040 ...

Table 1: Chemical compositions $(w / \%)$ of ceramics for surface coating

\begin{tabular}{|c|c|c|c|}
\hline Specimen No. & $\mathrm{Al}_{2} \mathrm{O}_{3}$ & $\mathrm{TiO}_{2}$ & $\mathrm{Cr}_{2} \mathrm{O}_{3}$ \\
\hline $\mathrm{S} 1$ & 99 & - & - \\
\hline $\mathrm{S} 2$ & - & 99 & - \\
\hline $\mathrm{S} 3$ & - & - & 99 \\
\hline $\mathrm{S} 4$ & 45 & 55 & - \\
\hline $\mathrm{S} 5$ & 55 & - & 45 \\
\hline $\mathrm{S} 6$ & - & 45 & 55 \\
\hline
\end{tabular}

Before spraying, the substrate was cleaned with acetone. In the present work $\mathrm{NiCr}$ bond coat of $20 \mu \mathrm{m}$ thickness was deposited on the substrate surface materials so as to compose an intermediate surface for the purpose of best adhesion property and the coating thickness with $200 \mu \mathrm{m}$ was deposited by plasma spraying process as shown in Figure 1.

\subsection{Thermal spraying equipment}

Sulzer Metco $3 \mathrm{MB}$ spraying guns were used for the deposition of ceramic oxide layers provided by $\mathrm{M} / \mathrm{s}$. SprayMet Technologies Pvt Ltd, Bangalore, India. The parameters used for the deposition of ceramic oxide coatings by thermal spraying process are shown in the Table 2.

Table 2: Guidelines of plasma spray process

\begin{tabular}{|c|c|}
\hline Gun & METCO 3MB \\
\hline Nozzle & GH \\
\hline Arc flow rate & $80-90 \mathrm{~L} / \mathrm{min}$ \\
\hline Arc pressure & $100-120 \mathrm{psi}$ \\
\hline Auxiliary gas flow rate & $20-35 \mathrm{~L} / \mathrm{min}$ \\
\hline Auxiliary gas pressure & $100 \mathrm{psi}$ \\
\hline Spray rate & $2.0-6.5 \mathrm{~kg} / \mathrm{h}$ \\
\hline Arc voltage & $60-70 \mathrm{~V}$ \\
\hline Arc current & $490-590 \mathrm{~A}$ \\
\hline Spray distance & $3-5$ inches \\
\hline Powder feed & $40-50$ grams $/ \mathrm{min}$ \\
\hline
\end{tabular}

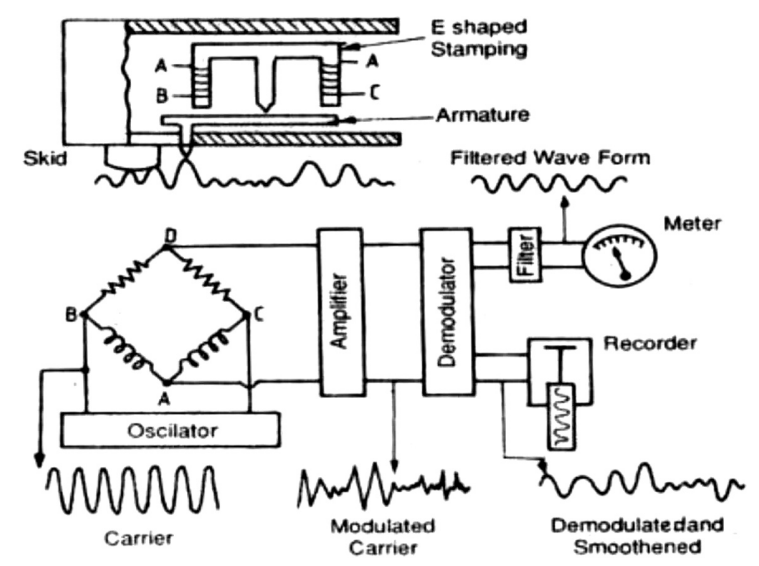

Figure 2: Schematic diagram of Talysurf instrument

\subsection{Characterization of coatings}

The microstructures of the specimens coated with $\mathrm{Al}_{2} \mathrm{O}_{3}, \mathrm{TiO}_{2}, \mathrm{Cr}_{2} \mathrm{O}_{3}$ and other compositions were characterized under a Scanning Electron Microscope (SEM) to study the microstructure of the substrate.

\subsection{Microhardness of the ceramic oxide coatings}

Hardness measurements were carried out to find the microhardness value of the AISI 1040 steel substrate and coated samples. The hardness test was carried out on the top surface of the coatings with a load of $250 \mathrm{~g}$ and dwell time period of $10 \mathrm{~s}$ and the average of three readings are shown in the Table 3.

Table 3: Hardness value of the specimen

\begin{tabular}{|c|c|}
\hline Specimens & $\begin{array}{c}\text { Vickers hardness number } \\
(\mathrm{HV})\end{array}$ \\
\hline $\mathrm{AISI} 1040$ & 230 \\
\hline $\mathrm{Al}_{2} \mathrm{O}_{3}$ & 776 \\
\hline $\mathrm{TiO}_{2}$ & 340 \\
\hline $\mathrm{Cr}_{2} \mathrm{O}_{3}$ & 960 \\
\hline $45 \% \mathrm{Al}_{2} \mathrm{O}_{3}+55 \% \mathrm{TiO}_{2}$ & 448 \\
\hline $55 \% \mathrm{Al}_{2} \mathrm{O}_{3}+45 \% \mathrm{Cr}_{2} \mathrm{O}_{3}$ & 560 \\
\hline $45 \% \mathrm{TiO}_{2}+55 \% \mathrm{Cr}_{2} \mathrm{O}_{3}$ & 652 \\
\hline
\end{tabular}

\subsection{Surface roughness measurements}

Talysurf instrument schematic sketch shown in Figure 2 was used to measure the surface roughness of the specimens before and after wear tests. The cut-off length was chosen as $0.8 \mathrm{~mm}$ for the instrument and a mean value of five readings was calculated.

\subsection{Wear test and evaluation}

Ceramic oxide coated specimens were subjected to dry wear tests by using a pin-on-disc wear testing device as per ASTM G99-04 standards. The $8 \mathrm{~mm}$ diameter and $30 \mathrm{~mm}$ length cylindrical pin samples coated with alumina, titania, chromia and combination of $45 \% \mathrm{Al}_{2} \mathrm{O}_{3}+$ $55 \% \mathrm{TiO}_{2}, 55 \% \mathrm{Al}_{2} \mathrm{O}_{3}+45 \% \mathrm{Cr}_{2} \mathrm{O}_{3}$, and $45 \% \mathrm{TiO}_{2}+$

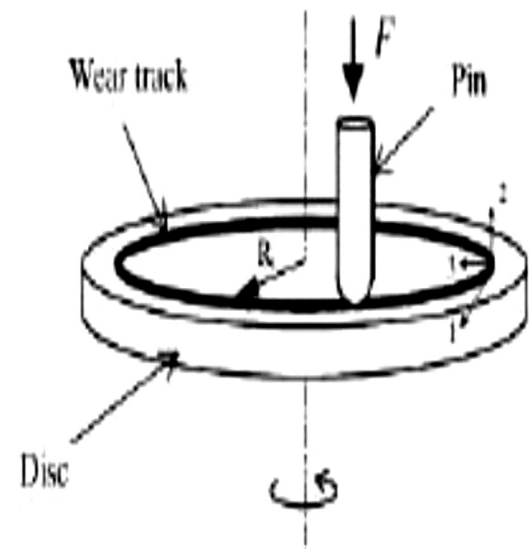

Figure 3: Pin-on-disc geometry 
D. R. PONNUSAMY RAJARATHNAM, M. JAYARAMAN: INVESTIGATION OF THE WEAR BEHAVIOUR OF AN AISI 1040 ...

$55 \% \mathrm{Cr}_{2} \mathrm{O}_{3}$ oxides of coating thickness $200 \mu \mathrm{m}$ were used as test materials. Counter face material made from hardened steel was used as a disc. For each sample drysliding wear tests were carried out three times against a constant load of $10 \mathrm{~N}$ for a sliding speed of $260 \mathrm{~min}^{-1}$, $525 \mathrm{~min}^{-1}$ and $790 \mathrm{~min}^{-1}$ under a sliding distance of $1000 \mathrm{~m}, 2000 \mathrm{~m}$ and $3000 \mathrm{~m}$ respectively. The corresponding weight losses of the coated specimens were calculated by means of an electronic weighing balance. The microstructural characteristics and wear behaviour were identified by means of the wear scars observed by using SEM for both the coated and uncoated specimens. The pin-on-disc geometry was shown in Figure 3.

\section{EXPERIMENTAL RESULTS AND DISCUSSION}

\subsection{Microstructure of ceramic oxide coating}

Scanning Electron Microscope (SEM) images of the AISI 1040 forged steel substrate and ceramic oxide powder samples at $200 \times$ magnification are shown in Figure 4. Figure 4a shows various elements present in AISI 1040 forged steel substrate and the increase of the ferrite grain size at the inner regions and ferrite, for example, similar to white regions and perlite, for example, similar to dark side regions were found. Figures $\mathbf{4 b}$ to $\mathbf{4 d}$ represent the morphological structure of the $\mathrm{Al}_{2} \mathrm{O}_{3}$, $\mathrm{TiO}_{2}$ and $\mathrm{Cr}_{2} \mathrm{O}_{3}$ particles. The $\mathrm{Al}_{2} \mathrm{O}_{3}$ and $\mathrm{TiO}_{2}$ powders have distinctive grain sizes, exhibited an irregular morphology and were sharp edged because of the agglomeration of essential particles. The alumina particles are generally nano-sized and the shape of particle is nonspherical. Particle density or true density gives data about the sort of material present in the sample. A particle density higher than $1.0 \mathrm{~g} / \mathrm{cc}$ is attributed to a high alumina content in the sample rather than the organic matter. The porosity is likewise sensibly high as expected. ${ }^{13}$ It demonstrates that the chromium oxide is in pure form and the particles are white colored nanoparticles that are almost rhombohedral and isolated.

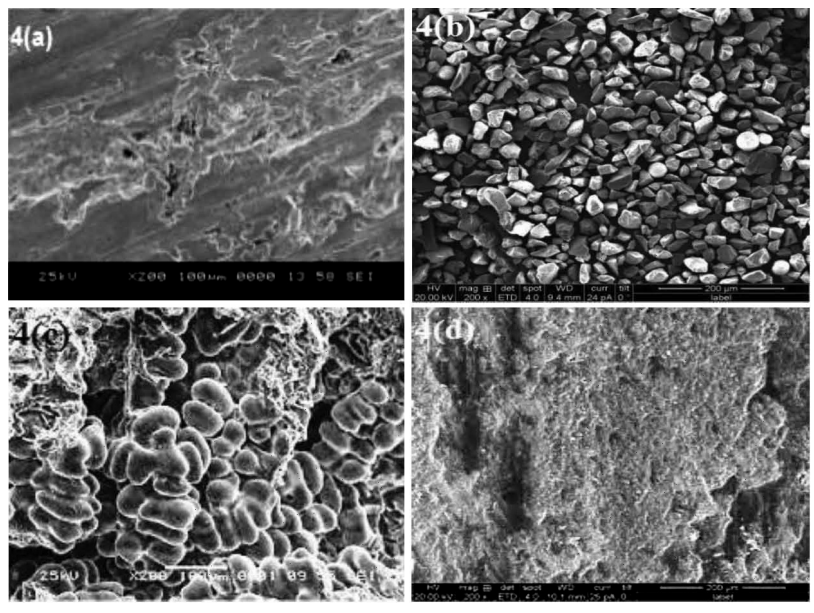

Figure 4: SEM images of steel substrate and ceramic oxides at 200x magnification: a) AISI 1040 forged steel, b) $\mathrm{Al}_{2} \mathrm{O}_{3}$, c) $\mathrm{TiO}_{2}$, d) $\mathrm{Cr}_{2} \mathrm{O}_{3}$
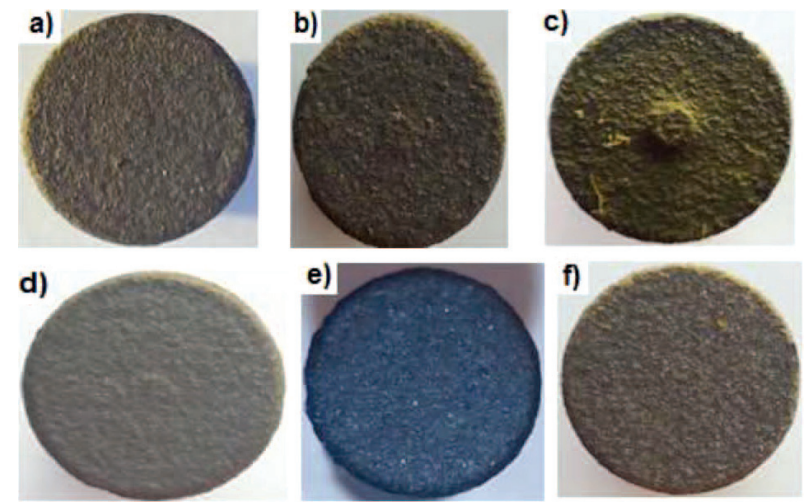

Figure 5: Photographic image of a) $\mathrm{Al}_{2} \mathrm{O}_{3}$, b) $\mathrm{TiO}_{2}$, c) $\mathrm{Cr}_{2} \mathrm{O}_{3}$ d) $45 \%$ $\mathrm{Al}_{2} \mathrm{O}_{3}+55 \% \mathrm{TiO}_{2}$, e) $55 \% \mathrm{Al}_{2} \mathrm{O}_{3}+45 \% \mathrm{Cr}_{2} \mathrm{O}_{3}$ and f) $45 \% \mathrm{TiO}_{2}+$ $55 \% \mathrm{Cr}_{2} \mathrm{O}_{3}$

Photographic images of the ceramic oxide coated specimens on AISI 1040 forged steel substrate are shown in Figure 5. Figure 5a to $5 \mathbf{f}$ show that the $\mathrm{Al}_{2} \mathrm{O}_{3}, \mathrm{TiO}_{2}$, $\mathrm{Cr}_{2} \mathrm{O}_{3}, 45 \% \mathrm{Al}_{2} \mathrm{O}_{3}+55 \% \mathrm{TiO}_{2}, 55 \% \mathrm{Al}_{2} \mathrm{O}_{3}+45 \%$ $\mathrm{Cr}_{2} \mathrm{O}_{3}$ and $45 \% \mathrm{TiO}_{2}+55 \% \mathrm{Cr}_{2} \mathrm{O}_{3}$ particles are homogenously distributed with less porosity present on the surface of the specimens. An examination of these images revealed that the substrate surface layer and the ceramic coating layer were homogenously fused and there were no pores, cracks, and spaces on the coating area.

\subsection{Surface-roughness measurement}

The surface roughness $\left(R_{\mathrm{a}}\right)$ values were higher for both the coated and uncoated samples before the wear test, whereas the $R_{\mathrm{a}}$ values were lower for both the coated and uncoated samples after the wear test. The recorded values are shown in Figure 6. The specimen coated with $55 \% \mathrm{Al}_{2} \mathrm{O}_{3}+45 \% \mathrm{Cr}_{2} \mathrm{O}_{3}$ and having a coating thickness of $200 \mu \mathrm{m}$ is shows a smaller $R_{\mathrm{a}}$ value before the wear test when compared to other values of coated and uncoated specimens. The specimen coated with (99\% of mass fractions) $\mathrm{TiO}_{2}$ and having a coating thickness of $200 \mu \mathrm{m}$ shows a lower $R_{\mathrm{a}}$ value after the wear test when compared to the other values of the coated and uncoated specimens after the wear test.

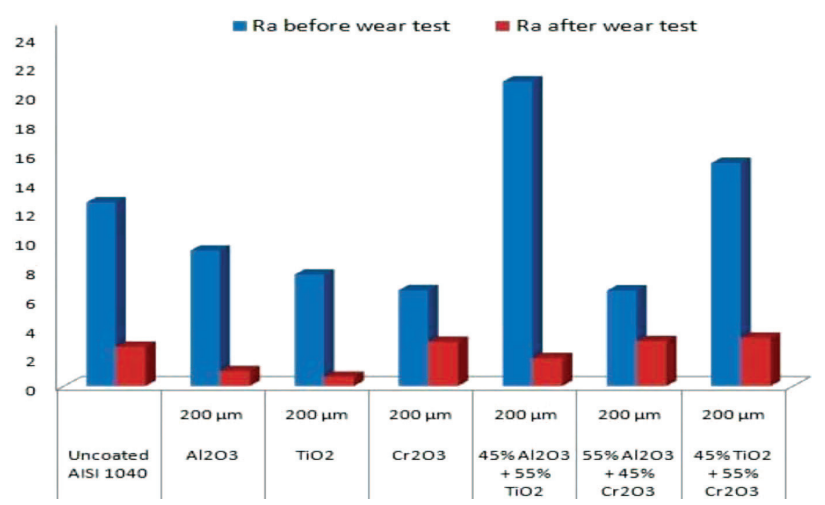

Figure 6: Surface roughness of coated and uncoated specimens 
D. R. PONNUSAMY RAJARATHNAM, M. JAYARAMAN: INVESTIGATION OF THE WEAR BEHAVIOUR OF AN AISI 1040 ...

QVICKERS HARDNESS NUMBER (HV)

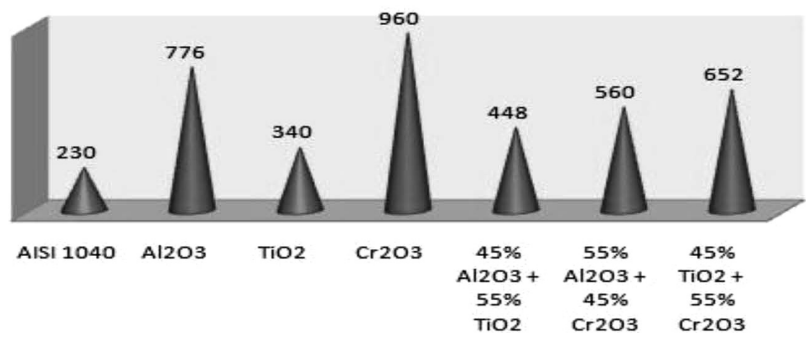

Figure 7: Microhardness of coated specimens and bare AISI 1040 forged steel

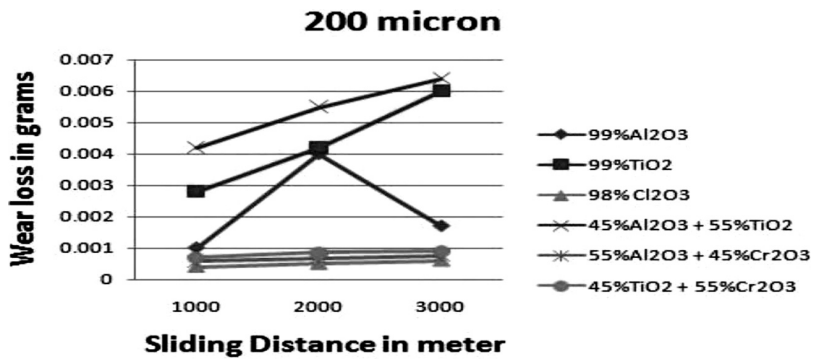

Figure 8: Effect of sliding distance on the wear loss for $200 \mu \mathrm{m}$

\subsection{Microhardness values of ceramic oxide coating}

Figure 7 shows the recorded microhardness values for different ceramic oxide coated and bare specimens.
From the recorded values, the $99 \% \mathrm{Cr}_{2} \mathrm{O}_{3}$ coated specimen has the highest microhardness value when compared to the other coated and uncoated specimens.

\subsection{Wear-rate performance of ceramic oxide coated specimens}

By using a pin-on-disc apparatus, dry-sliding wear tests were carried out on the ceramic oxide coated and uncoated AISI 1040 specimens according to the ASTM G99-04 standard wear test. The effect of sliding distance in the wear loss of the uncoated and coated specimens at a constant load of $10 \mathrm{~N}$ for the different composition coating powder is shown in Figure 8.

The specimen coated with $99 \% \mathrm{Cr}_{2} \mathrm{O}_{3}$ and having a thickness $200 \mu \mathrm{m}$ has comparatively less wear loss for all the sliding distances rather than the uncoated AISI 1040 forged steel specimen and other combinations of ceramic-oxide-coated specimens. The specimen coated with $\mathrm{Al}_{2} \mathrm{O}_{3}-55 \% \quad \mathrm{TiO}_{2}$ shows a higher wear loss at all the sliding distances when compared to all the other coated specimens. SEM images of ceramic oxide coated specimens and AISI 1040 forged steel after wear test under a constant load of $10 \mathrm{~N}$ are shown in Figures 9. From Figure 9a to $9 f$ it was observed that the $\mathrm{Al}_{2} \mathrm{O}_{3}-55 \% \mathrm{TiO}_{2}$ coated specimen experienced serious wear condition described by shearing and plastic distortion and the surface of the substrate has turned out to be rough and
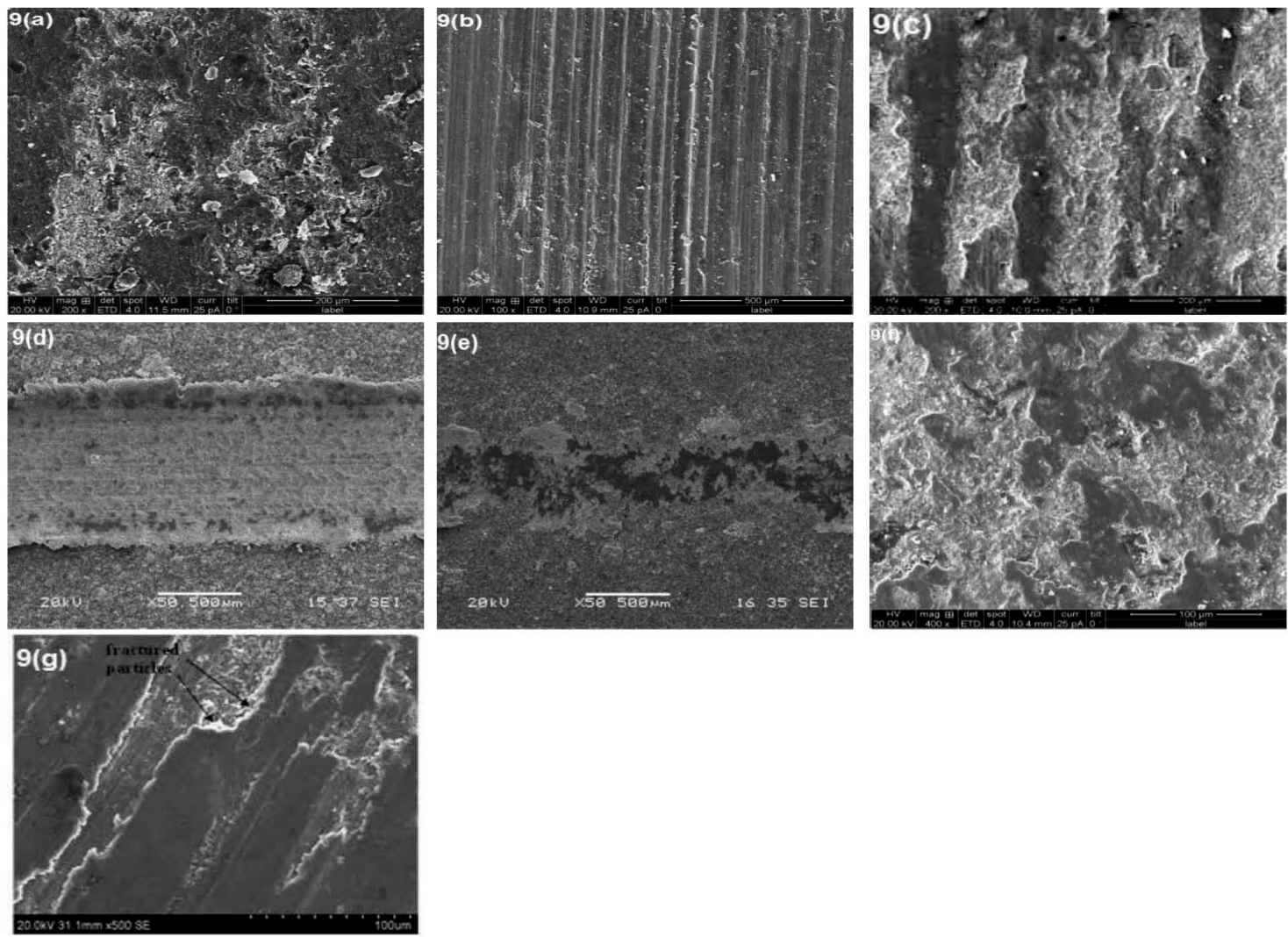

Figure 9: $\mathrm{SEM}$ microstructure after wear test of: a) $\mathrm{Al}_{2} \mathrm{O}_{3}$, b) $\mathrm{TiO}_{2}$, c) $\mathrm{Cr}_{2} \mathrm{O}_{3}$, d) $45 \mathrm{Al}_{2} \mathrm{O}_{3}+55 \mathrm{TiO}_{2}$, e) $55 \mathrm{Al}_{2} \mathrm{O}_{3}+45 \mathrm{Cr}_{2} \mathrm{O}_{3}$, f) $45 \mathrm{TiO}_{2}+55$ $\mathrm{Cr}_{2} \mathrm{O}_{3}$, g) AISI 1040 forged steel 
debris formed because of the wear. The $\mathrm{Al}_{2} \mathrm{O}_{3}$-coated specimen had a wear mechanism on the surface in the form of flaky micro-cracks. This could be attributed to the high hardness values of the specimens. Micro-cracks occur if a critical value is exceeded in loading and abrasive wear also takes place in relation to the fracture toughness of the abraded material. The $\mathrm{TiO}_{2}$-coated specimen showed that the wear mechanism on the surface formed micro-cutting of various widths along with plastic deformation because of micro crackings. Figure $9 \mathrm{~g}$ reveals that the transfer of the materials that occurred from the pin to the disc. The debris produced throughout the test was deposited on both sides of the wear track. Over the wear track a few patches of the initial surface are observed, indicating that the transferred steel film was detached as a result of a fatigue process.

\section{CONCLUSIONS}

The AISI 1040 forged steel substrate was coated with alumina, titania, chromia individually and again with different combinations of ceramic oxides such as $45 \%$ $\mathrm{Al}_{2} \mathrm{O}_{3}+55 \% \mathrm{TiO}_{2}, 55 \% \mathrm{Al}_{2} \mathrm{O}_{3}+45 \% \mathrm{Cr}_{2} \mathrm{O}_{3}$, and $45 \%$ $\mathrm{TiO}_{2}+55 \% \mathrm{Cr}_{2} \mathrm{O}_{3}$ by using a plasma-spraying process with an intermediate bond coat of $\mathrm{NiCr}$, SEM tests were carried out to determine the surface roughness and adhesion of the coating onto the AISI 1040 substrate.

The specimen coated with $99 \% \mathrm{Cr}_{2} \mathrm{O}_{3}$ has higher microhardness values among all the ceramic-oxidecoated specimens, which was followed by $99 \% \mathrm{Al}_{2} \mathrm{O}_{3}$, $45 \% \mathrm{TiO}_{2}+55 \% \mathrm{Cr}_{2} \mathrm{O}_{3}, 55 \% \mathrm{Al}_{2} \mathrm{O}_{3}+45 \% \mathrm{Cr}_{2} \mathrm{O}_{3}$. The lowest hardness value was obtained from the ceramic oxide coating surface with a mixture proportion of $45 \%$ $\mathrm{Al}_{2} \mathrm{O}_{3}+55 \% \mathrm{TiO}_{2}$.

The chromia-coated specimen showed excellent wear property when compared to other coating materials due to its excellent adhesion to the base metal.

The increase in the weight percentage of $\mathrm{TiO}_{2}$ in the $\mathrm{Al}_{2} \mathrm{O}_{3}$ ceramic material affects the microhardness value of the specimens in a decreasing manner.

The microhardness values of the coated specimens influence the wear loss. The specimens having higher microhardness also have a higher wear resistance and cause less wear loss.

If the weight percentage of $\mathrm{TiO}_{2}$ in $\mathrm{Cr}_{2} \mathrm{O}_{3}$ ceramic materials increases, this decreases the microhardness value of the specimens.

From the experimental results it can be concluded that the pure $99 \% \mathrm{Cr}_{2} \mathrm{O}_{3}$ coated AISI 1040 forged steel specimen showed better wear resistance property due to dense, compact, defects free and good adhesion charac- teristics, while compared to other coating materials. Hence, it is recommended for surface coating on the top mill roll shafts used in sugarcane industries to increase the wear resistance of the shaft.

\section{Acknowledgement}

The research work was supported by my father Mr. D. Ponnusamy and my spouse Mrs B. Malathi. Special thanks to Professor Dr. K. K. Ramasamy and Dr. M. Premkumar from Paavai Engineering College, Namakkal, India, for their valuable help.

\section{REFERENCES}

${ }^{1}$ S.-H. Yao, Comparative study on wear performance of traditional and nano structured $\mathrm{Al}_{2} \mathrm{O}_{3}-13$ wt. $\% \mathrm{TiO}_{2}$ air plasma spray coatings, J. Ceram. Silikaty, 59 (2015) 1, 59-63

${ }^{2}$ Y. Sert, N. Toplan, Tribological behaviour of a plasma - sprayed $\mathrm{Al}_{2} \mathrm{O}_{3}-\mathrm{TiO}_{2}-\mathrm{Cr}_{2} \mathrm{O}_{3}$ coating, Mater. Technol., 47 (2013) 2, 181-183

${ }^{3}$ C. A. Berkath, A. Khan, Dr. Anilkumar, P. M. Suresh, Tribological behaviour of a plasma - sprayed $\mathrm{Al}_{2} \mathrm{O}_{3}-\mathrm{TiO}_{2}$ coating on Al-6082T6 substrate, Int. J. of Inno. Res. in Sci., Eng. and Techno., 3 (2014) 6, 13956-13963

${ }^{4}$ M. H. Korkut, Y. Kucuk, A. C. Karaoglanl, A. Erdogan, Y. Er, M. S. Gok, Effect of the abrasive grit size on the wear behaviour of ceramic coatings during a micro-abrasion test, Mater. Technol., 47 (2013) 6, 695-699

${ }^{5}$ S. Islak, S. Buytoz, I. Somunkiran, E. Ersoz, N. Tosun, N. Orhan, J. Stokes, M. Saleem Hashmi, Effect on microstructure of $\mathrm{TiO}_{2}$ rate in $\mathrm{Al}_{2} \mathrm{O}_{3}-\mathrm{TiO}_{2}$ composite coating produced using plasma spray method, Optoelectro. Adv. Mater. - Rapid Comm., 6 (2012) 9-10, 844-849

${ }^{6}$ S. Salman, R. Kose, L. Urtekin, F. Findik, An investigation of different ceramic coating thermal properties, Mater. Des., 27 (2006) 7, 585-590, doi:10.1016/j.matdes.2004.12.010

${ }^{7}$ M. S. Kumar, S. Natarajan, Analysis of tribological factors on dry sliding wear behaviour of thermally sprayed carbide and ceramic coatings by taguchi method, Int. J. of Eng. Sci. Tech., 3 (2011) 4, 3336-3347

${ }^{8}$ G. Bolelli, V. Cannillo, L. Lusvarghi, T. Manfredini, Wear behaviour of thermally sprayed ceramic oxide coatings, Wear, 261 (2006), 1298-1315, doi:10.1016/j.wear. 2006.03.023

${ }^{9}$ A. Prasad, D. Gupta, M. R. Sankar, A. N. Reddy, Experimental investigations of $\mathrm{Ni} / \mathrm{La}_{2} \mathrm{O}_{3}$ composite micro-cladding on AISI 1040 steel through microwave irradiation, 5th Int. \& 26th All India Manufacturing Techno., Des. and Res. Conference, 2014, 55-61

${ }^{10}$ M. S. Gok, The effect of different ceramics on the abrasive wear behavior of coating surface produced by the plasma process, Int. J. of the Phy. Sci., 5 (2010) 5, 535-546

${ }^{11}$ P. Gadhari, P. Sahoo, Wear resistance improvement of electroless $\mathrm{Ni}-\mathrm{P}-\mathrm{Al}_{2} \mathrm{O}_{3}$ composite coating by optimizing process parameters using taguchi technique, Int. J. of Mater. Chem. and Phy., 1 (2015) 1 , 1-10, http:// creativecommons.org/ licenses/by-nc/4.0/

${ }^{12}$ M. Yunus, J. F. Rahman, Optimization of usage parameters of ceramic coatings in high temperature applications using taguchi design, Int. J. of Eng. Sci. and Techno., 3 (2011) 8, 6364-6371

${ }^{13}$ C. G. Schull, The determination of pore size distribution from gas adsorption data, J. Am. Chem. Soc ., 70 (1948) 4,1405-1410 